\title{
Analyzing streamflow changes: irrigation-enhanced interaction between aquifer and streamflow in the Republican River basin
}

\author{
R. Zeng and X. Cai \\ Ven Te Chow Hydrosystems Laboratory, Department of Civil and Environmental Engineering, \\ University of Illinois at Urbana-Champaign, Urbana, Illinois, USA
}

Correspondence to: X. Cai (xmcai@illinois.edu)

Received: 1 June 2013 - Published in Hydrol. Earth Syst. Sci. Discuss.: 19 June 2013

Revised: 20 December 2013 - Accepted: 2 January 2014 - Published: 10 February 2014

\begin{abstract}
Groundwater-fed irrigation has altered surface and groundwater interactions in the Republic River basin (RRB) in the midwestern United States, where agriculture heavily depends on irrigation. The decreasing flow trend recorded at the RRB gauging station since the 1950s reflects the synthetical effect of dynamic interactions between surface water and groundwater systems, which has been enhanced by groundwater pumping and irrigation return flow. This study uses a systematic modeling approach to analyze the conjunctive effects of pumping and return flow on streamflow. A watershed management model, the Soil and Water Assessment Tool (SWAT), is modified and established for the Frenchman Creek basin (FCB), a subbasin of RRB, to examine the causes of streamflow changes. The baseflow component in SWAT is linked to aquifer storage so that the model can simulate the combined effects of groundwater pumping and irrigation return flow on natural streamflow. Results show that irrigation has not only depleted streamflow but also changed the flow pattern and seasonal variability. The changes can be decomposed into decrease in the slow component (baseflow) and increase in the fast components (surface and subsurface flow). Since the fast components are subject to higher variability than the slow component, the annual streamflow variability is amplified. Agricultural water use in this region also has changed the groundwater storage seasonal regime from the pattern of "summer recharge and winter discharge" in the past to "summer discharge and winter recharge" at present. This challenges the existing groundwater modeling, which usually assumes fixed recharge pattern and rates.
\end{abstract}

\section{Introduction}

Irrigation has contributed to the agricultural production increase during the past decades, becoming the largest water consumption sector throughout the world, accounting for about $70 \%$ of the global freshwater withdrawals and $90 \%$ of consumptive water uses (Siebert et al., 2010). In the United States, irrigation is located in the states where average annual precipitation is typically less than 20 inches and thereby is insufficient for crop consumption. As the surface water resources is prone to be affected by climate variability and pollution, and needs infrastructure investment for storage (i.e., reservoir) and delivery (i.e., channels), groundwater has replaced surface water as the major water source in many places. In 2005, 13 western states consumed nearly $90 \%$ of the groundwater used for irrigation, among which groundwater was the primary source for irrigation in Nebraska, Arkansas, Texas, Kansas, Mississippi, and Missouri (Kenny et al., 2009).

Groundwater-fed irrigation alters hydrological processes across a range of scales. The estimated global groundwater depletion since the year of 1900 is equivalent to a $12.6 \mathrm{~mm}$ rise in sea level, which accounts for more than $6 \%$ of total sea-level rise (Konikow, 2011). Nonrenewable groundwater abstraction contributes approximately $20 \%$ to the global gross irrigation water demand in the year of 2000 (Wada et al., 2012). At the regional scale, the rapid development of groundwater pumping after the 1950s has changed the interactions of surface water and groundwater and caused water right conflicts between surface water users and groundwater users in the western states of the US (Sophocleous, 2010; Gleeson et al., 2012). At a local scale, the changes 
in groundwater storage and flux affect the terrestrial environment and fluvial biota (Alley et al., 2002). The interactions between groundwater and lakes, wetlands, estuaries, and oceans play an important role for the distribution of biota and biogeochemical processes, such as fish spawning areas (Malcolm et al., 2008).

Moreover, the aggregation of the disruption of the local hydrological cycle by intensive irrigation has been found to affect the regional climate, which would further affect the irrigation requirement, leading to a feedback loop. Irrigation impacts land surface processes by altering the partition of energy and water through the interactions between soil profile, land surface flux and groundwater depth. Studies have shown that irrigation increases surface latent heat flux and dew point temperature, while decreases sensible heat flux and nearground temperature (Adegoke et al., 2003; Tang et al., 2007). DeAngelis et al. (2010) found the intensive groundwater pumping for agricultural use over the Great Plains leads to increased vapor, which aggregates to enhance downwind precipitation. According to Ferguson and Maxwell (2012), the effect of water management (e.g., pumping and irrigation) on terrestrial water and energy budgets is even comparable in magnitude to the impact of climate change (e.g., changes in temperature and precipitation). Thus, understanding the details of how irrigation affects hydrological processes will help in understanding hydrological alterations over watershed scales, as well as providing support for conjunctive management of surface water and groundwater resources in terms of satisfying both human and environmental water needs.

While the complex feedbacks between irrigation and land surface processes have been less studied because of difficulties in observation data, the impact of large-scale pumping on aquifer storage and streamflow is more likely to be observed (McGuire, 2009) and hence has been studied intensively since Theis (1940). Jenkins (1968) analyzed the stream depletion volume and residual timing of pumping by introducing the SDF (stream depletion factor), which measures how fast groundwater withdrawal transfers from aquifer storage to stream depletion, to account for the transient effect of pumping. Kendy and Bredehoeft (2006) assessed the response of streamflow to pumping wells with different distances to the river. They found that stream depletion caused by near-stream pumping wells quickly reaches equilibrium and responses temporally in phase with pumping; however, far-away wells cause smaller stream depletion and seasonal fluctuation, and a greater portion of the depletion occurs during post-irrigation season. They also examined the impact of irrigation efficiency on the streamflow seasonality and found that when the irrigation system delivers water inefficiently, irrigation return flow recharges the aquifer during irrigation season and discharges to stream during post-irrigation season, boosting fall and winter low flows. The return flow to stream is a loss of irrigation water but a gain of streamflow in many cases. For example, Gosain et al. (2005) studied return flow from irrigation introduced by canal in the Palleru River basin. They found that return flow accounts for over $50 \%$ of irrigation application, much higher than the usual rule-ofthumb value of 10-20\%. However, in many studies, return flow is simply accounted as a fixed portion of irrigation water application and is added back to streamflow. This will probably ignore the actual quantity and temporal variation of the return flow contribution to streamflow, which might be influential during growing seasons.

The combined effects of the two processes, pumping and return flow, on streamflow have not been well represented by the models used for the analysis. Few current groundwater models explicitly simulate the impact of irrigation return flow on aquifer-stream interaction; while surface hydrological models usually do not simulate the impact of groundwater pumping on baseflow appropriately. Both modeling groups capture one aspect of the picture, but not the whole. For example, the aquifer recharge, evapotranspiration and channel loss in groundwater models are usually decided through calibration and treated as fixed values during the simulation period. Attempts to simulate crop processes, such as with the Farm Process package of MODFLOW, improve the estimate of crop water requirement (Schmid et al., 2006). However, those models usually do not simulate the soil profile, which plays an important role in determining crop growth, recharge and evapotranspiration (Rodriguez-Iturbe et al., 1999). Some surface hydrological models have detailed representations of crop irrigation requirement and soil moisture, but usually assume that groundwater-fed irrigation has no impact on the source (i.e., aquifer storage) (Sophocleous and Perkins, 2000). It is important to note irrigation affects spatially distributed hydrological processes and land-energy fluxes depending on the location of irrigated crops (Ferguson and Maxwell, 2011). The streamflow recorded at gauging stations is the result of dynamic interactions between surface water and groundwater systems over different temporal and spatial scales, where return flow plays a critical role in partially compensating the stream depletion caused by groundwater pumping and changing the process of streamflow response to climatic variability through the conjunctive management of surface water and groundwater systems.

Although hydrological research communities agree that surface water and groundwater systems compose a holistic entity that requires an integrated modeling approach, models for the integrated systems are currently not well developed (Sophocleous and Perkins, 2000; Sophocleous, 2010). In this study, the Soil and Water Assessment Tool (SWAT) (Arnold et al., 1998), a widely used watershed management model is modified by linking the baseflow component to aquifer storage in order to simulate the complex effect of groundwater pumping and irrigation return flow on streamflow, and to understand the impact of irrigated agricultural development on streamflow change. The model is applied to the Frenchman Creek basin (FCB), a subbasin of the Republican River basin (RRB), where groundwater-fed irrigation has been developed 


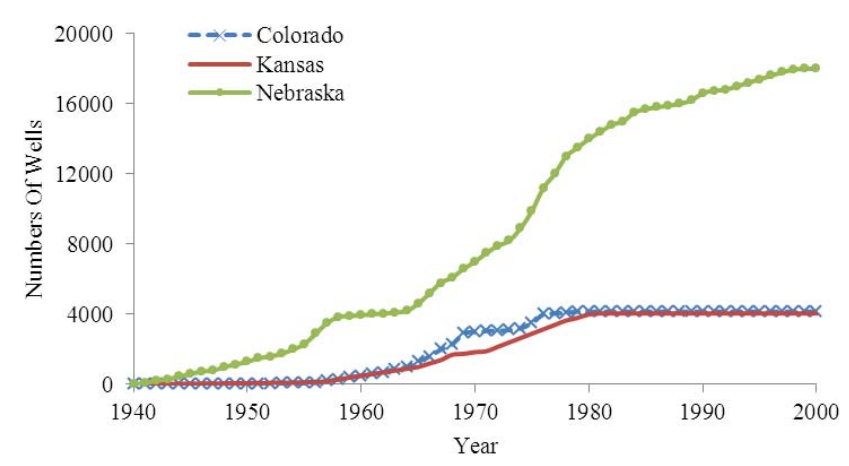

Fig. 1. Accumulative number of active groundwater pumping wells of Colorado, Kansas and Nebraska in RRB (adopted from Republican River Compact Administration http://www.republicanrivercompact.org/v12p). Starting in the 1960s, groundwater-fed irrigation has become the largest aquifer water use in this region.

in the area since the 1950s and considerable streamflow depletion has been reported (Burt et al., 2002). This case study will then illustrate the streamflow change in the context of stream-aquifer interaction under the effects of pumping and return flow.

\section{Study area and model description}

\subsection{Frenchman Creek basin}

The RRB, lying above the northern Ogallala Aquifer, is shared by Colorado, Nebraska, and Kansas. The FCB, a subbasin of RRB, lays above the Ogallala Formation, which is composed mainly of silt, sand, gravel, and clay-rock debris that have been washed off the face of the Rocky Mountains and other more local sources over the past several million years (Gutentag, 1984). Recharge to the High Plains aquifer is primarily fed by precipitation through infiltration. Natural discharge from the High Plains aquifer goes to springs, seeps, and streams, as well as by evapotranspiration flux. However, the pumping for irrigated crops now becomes a significant discharge from the aquifer. The Ogallala Formation has the greatest saturated thickness, and the portion in FCB ranges from 200 to $300 \mathrm{ft}$. above the Permian bedrock (Miller et al., 1997). The aquifer underlying the FCB is conceptualized as a one-layer unconfined aquifer above a non-leaky bedrock in the groundwater model established by the Republican River Compact Administration (RRCA). Groundwaterfed irrigation since the 1950s (shown in Fig. 1 as the pumping well numbers) in this region has reduced aquifer storage and caused stream depletion problems in the RRB as shown in Fig. 2. Groundwater storage in the High Plains aquifer in 2009 was about 2.9 billion acre-ft., showing a decline of about 274 million acre-ft. (or about 9\%) from predevelopment storage (McGuire, 2011). Szilagyi (2001) found the

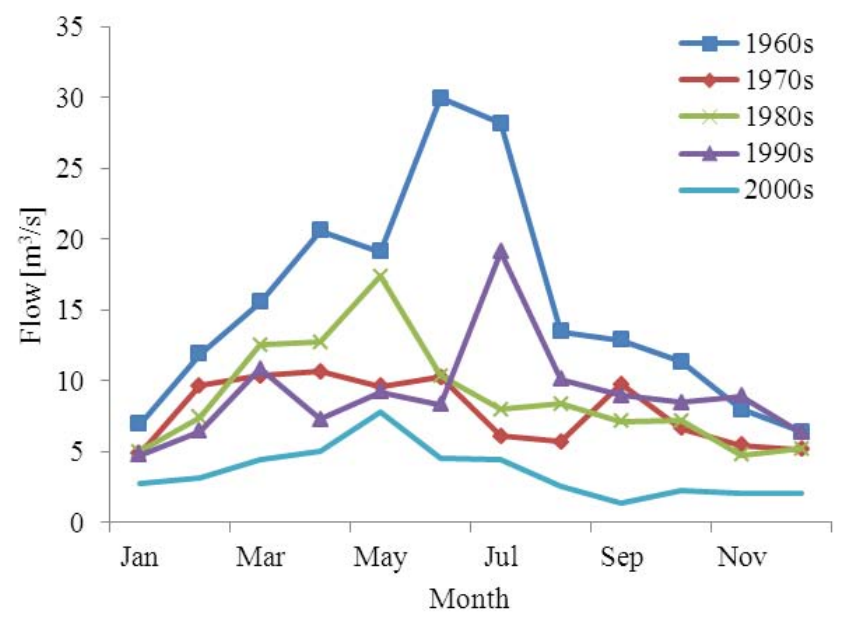

Fig. 2. Monthly flow regime (monthly average flow by each decade) at RRB outlet (source: USGS Station 06853500).

Republican River annual streamflow has declined by $61 \%$ without a significant change in climate. Disputes about surface water and groundwater rights lead to a legal issue among the states sharing the aquifer.

The Frenchman Creek, about $166 \mathrm{mi}$. long, flows from Colorado to Nebraska. The average annual precipitation in this region from 1941 to 1994 was about $443 \mathrm{~mm}$ according to the Automated Weather Data Network with the High Plain Regional Climate Center (HPRCC, 2010), which increases from east to west as the effect of elevation gradient; annual potential evapotranspiration in this region is about $1100 \mathrm{~mm}$. The crop in the basin is heavily dependent on central pivot irrigation from pumping wells. Although lacking of well documented groundwater consumptive use data, studies have shown a strong statistical relationship between the number of pumping wells and stream depletion in this watershed (Burt et al., 2002). In this study, the pumping is estimated from annual irrigated crop acreage from the National Agricultural Statistics Service (USDA, 1999). The FCB has experienced stream depletion over the past decades. The majority of the flow in the watershed was sustained by the Ogallala Aquifer system. The perennial drainage section of the headwater, once located several miles west of the Nebraska-Colorado border, now shrinks downstream by several miles east of the border.

It is widely accepted that streamflow decreases in the RRB have been caused by extensive pumping, but the decreases can also be related to climate change. We first examine the climate during the last decades to find out if the climate can also explain the streamflow changes. We divide the climate time series into two equal lengths (pre- and post1970). The spatially averaged annual precipitation and temperature since the 1940s are shown in Fig. 4, respectively. The annual precipitation exhibits fluctuation ranging from 300 to $600 \mathrm{~mm}$. The mean annual precipitation is 452 and 


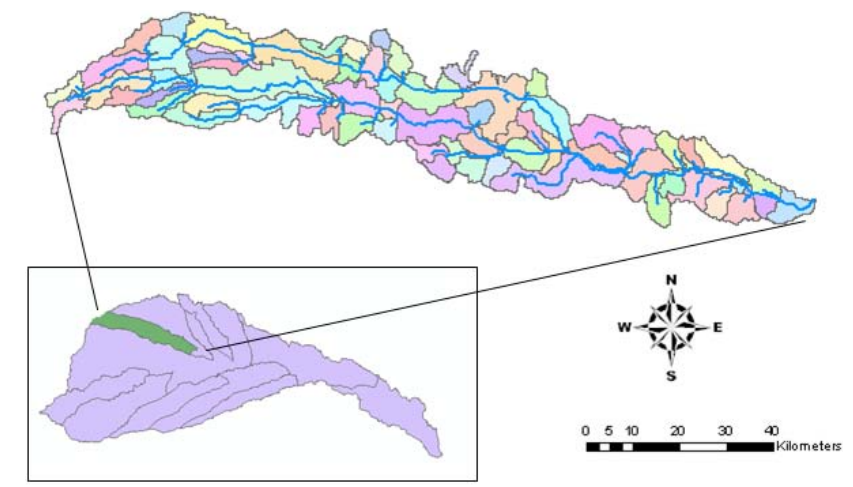

Fig. 3. Domain of the Frenchman Creek basin in the Republican River basin.

$459 \mathrm{~mm}$ for pre-1970 and post-1970, respectively, and the standard deviation remain unchanged at around $95 \mathrm{~mm}$. The annual average minimum temperature slightly increases from 1.96 to $2.13^{\circ} \mathrm{C}$; the annual average maximum temperature slightly decreases from 18.07 to $17.92^{\circ} \mathrm{C}$. Standard deviation of the both remain unchanged at around $0.7^{\circ} \mathrm{C}$. Moreover, the seasonality of climatic variables was examined by averaging the monthly data for each decade; it is found that the pattern remains unchanged, i.e., the rainfall season is still in phase with the warm season. Actually, a slight decrease is found in the diurnal temperature range (difference between daily maximum and minimum temperature), which can be the result of irrigation. Irrigation leads to increased evapotranspiration and humidity above farmland, converting more radiative energy into latent heat, which results in redistribution of surface energy between latent heat, sensible heat and ground heat flux. Adegoke et al. (2003) compared the surface energy budget between irrigated and non-irrigated farmland in Nebraska. They found that due to the "cooling effect", irrigation contributes to a $15 \%$ decrease in sensible heat and $1.2{ }^{\circ} \mathrm{C}$ decrease in near-ground temperature. Thus, based on the observed data and some relevant analyses, changes in climate forcing cannot explain the significant decrease in streamflow, which is then mostly likely due to other factors such as land use and water use in the region.

\subsection{Watershed management model}

SWAT, a semi-distributed, physically based watershed model, includes components such as weather, hydrology, sediment transport, crop growth, water quality, and agricultural management, and has been widely applied to assessing water quantity and quality, land use and climate change impacts, and agriculture management in heterogeneous watersheds (Gassman et al., 2007). Irrigation is simulated by an auto-irrigation subroutine, i.e., irrigation is applied when the soil moisture of a crop field is below the prescribed irrigation triggering threshold during the crop growing season.

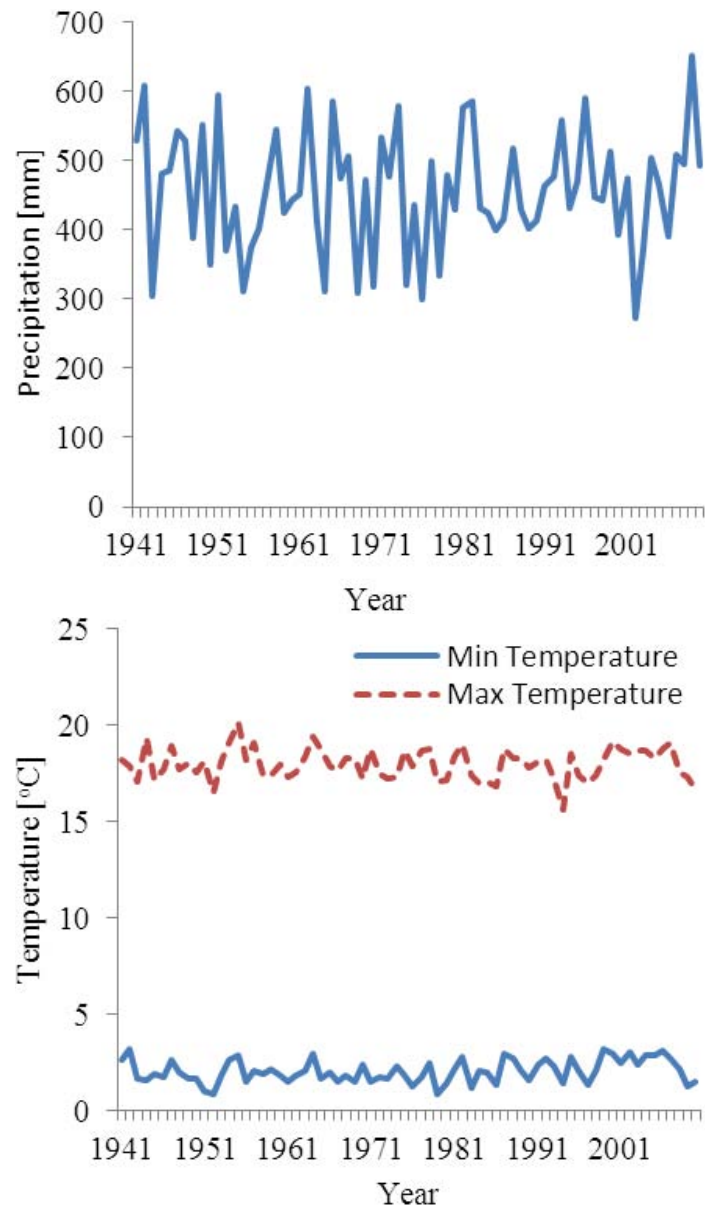

Fig. 4. Annual precipitation (left) and maximum/mininimum temperature (right) in FCB. The climate exhibits no significant change during the last several decades. The slight decrease in diurnal temperature range implies the impact of irrigation on land surface energy redistribution.

In watersheds with intensive irrigation, irrigation return flow is an important human-induced hydrologic process, but it is usually ignored or oversimplified in some existing agricultural watershed models. Irrigation return flow includes both a vertical and a horizontal component. The vertical component infiltrates through the soil profile and recharge aquifer, which will then affect aquifer storage and further baseflow. The horizontal component moves in the soil profile and contributes to rivers as subsurface flow. The different return flow paths result in different processes and travel times. Moreover, irrigation changes soil moisture, and in turn the soil moisture dynamics affects the timing and quantity of irrigation return flow. SWAT simulates runoff from surface flow, subsurface flow and baseflow, separately. Thus the SWAT model is chosen to simulate the effect of irrigation return flow on all components of runoff, i.e., the baseflow and the fast flow components. 
In the SWAT model the baseflow is calculated by the following equation:

$$
Q_{\mathrm{gw}, i}=Q_{\mathrm{gw}, i-1} \operatorname{Exp}(-\alpha \Delta t)+W_{\mathrm{rchrg}, i}[1-\operatorname{Exp}(-\alpha \Delta t)],
$$

where $i$ is the simulation day, $\Delta t$ is the time step (i.e., one day), $Q_{\mathrm{gw}, i}$ is the baseflow, $W_{\text {rchrg }}$ is the shallow aquifer recharge from soil profile, and $\alpha$ is the baseflow recession coefficient. In Eq. (1), baseflow depends on the baseflow from the previous day (representing recession process) and recharge (representing the effect of rain-induced recharge on baseflow). However, the process reflecting the impact of groundwater pumping on streamflow is missing in Eq. (1). Groundwater pumping first captures aquifer storage, if the storage is not fully recovered, then the induced water table gradient would change the discharge (i.e., baseflow), causing stream depletion. To represent this process, alternatively, the baseflow component in SWAT has been modified based on the shallow (unconfined) aquifer water storage $\left(S_{\mathrm{sh}}\right)$ :

$Q_{\mathrm{gw}, i}=\alpha \quad S_{\mathrm{sh}, i}$,

and storage is updated through shallow aquifer water balance:

$S_{\mathrm{sh}, i}=S_{\mathrm{sh}, i-1}+W_{\mathrm{rchrg}, i}-Q_{\mathrm{gw}, i}-W_{\mathrm{revap}, i}-W_{\mathrm{pump}, i}$,

where $W_{\text {revap }}$ is the water evapotranspirated from the shallow aquifer by deep root vegetation; $W_{\text {pump }}$ is the water pumped from aquifer for irrigation use, which is based on the soil moisture content. Note that Eq. (2) represents a linear storage model (Chow et al., 1988). If there is no recharge, i.e., evapotranspiration and pumping, baseflow is an ordinary differential equation and Eq. (1), originally used in SWAT, can be derived from Eqs. (2) and (3). Thus the baseflow recession parameter is consistently used in the original and modified model. However, the modified equation requires one more parameter, the initial storage, which needs to be calibrated from model outputs. Note that Eq. (3) assumes groundwater lateral flux is negligible in the water balance equation. This assumption is validated by checking the water table contour in the study area. The water table contour in 1979 and 1995 are obtained from the Conservation and Survey Division in the University of Nebraska (Swinehart and Richmond, 1994). Those contours show that the groundwater in FCB flows from west to east following the topographic gradient. Since the water table contour is generally perpendicular to the boundary of the FCB within Nebraska, the groundwater lateral flow exchange with the adjacent aquifer is negligible.

The irrigated cropland acreage over years is an important model input, which determines the timing and location of groundwater pumping for irrigation. Since irrigation is the major water use in this watershed, the spatial and temporal expansion of irrigated crop water use affects the spatial heterogeneity and temporal variability of groundwater storage change through pumping, which further affects the interaction between surface and ground water, especially the contribution of baseflow to river streams. Running the SWAT model over years will capture the temporal variability of groundwater storage and then streamflow; the spatial variability of groundwater storage, baseflow and the total streamflow is related to the spatial distribution of irrigation pumping over the spatial units of the SWAT model (i.e., hydrologic response units represented by watersheds of a certain stream order).

To calibrate the model for the FCB, the outlet of the watershed is chosen at the upstream of Enders Reservoir (USGS siteID 06831500) to exclude the impacts of surface water regulation on streamflow. The model is calibrated and validated for the periods 1981-1985 and 1986-1990, respectively, with a multiple-objective genetic algorithm. The rootmean-square error (RMSE) and logarithm of the RMSE of streamflow are chosen as calibration criteria to consider both high flow and low flow. The SWAT model is calibrated by the total streamflow (i.e., including both baseflow from aquifer discharge and surface runoff). The RMSE of crop yield is also set as criteria, mainly to calibrate the auto-irrigation trigger parameter, thus the water management activity (i.e., pumping amount and timing) is retrieved through flow and crop data. It is worth noting that the best calibration result of the original SWAT model does not even capture the stream decline trend. For details on model data, parameters, and calibration procedures, the reader is referred to Zeng (2012).

\section{Results}

\subsection{Streamflow change due to land use and pumping}

The SWAT model is applied to three land use and water management scenarios, all under historical climate forcing data: (1) no agricultural development in this region; (2) land use change is represented by historical crop area but no irrigation (i.e., rain-fed crop); (3) historical crop area with groundwater pumping simulated by auto-irrigation in SWAT. The auto-irrigation module of SWAT calibrated to the case study watershed is used to determine the irrigation scheduling, including the water application timing and amount. By comparing the results from these scenarios, the impacts of land use and groundwater irrigation can be identified.

In the "no agricultural development" scenario, the land use is fixed as the level in the 1940s, when most of the land cover in the region was either grassland or ranch land and only a small fraction of the land was used for irrigated agriculture, which is negligible compared to the large irrigation water consumption after quick development in the 1960s and 1970s. Under this "natural" scenario, the mean streamflow is 3.24 and $3.08 \mathrm{~m}^{3} \mathrm{~s}^{-1}$ during pre-1970s and post-1970s periods, respectively, showing a very small change. This small decline may also be caused by agricultural activity because some parts of the basin were used for crop production before the 1940s. 


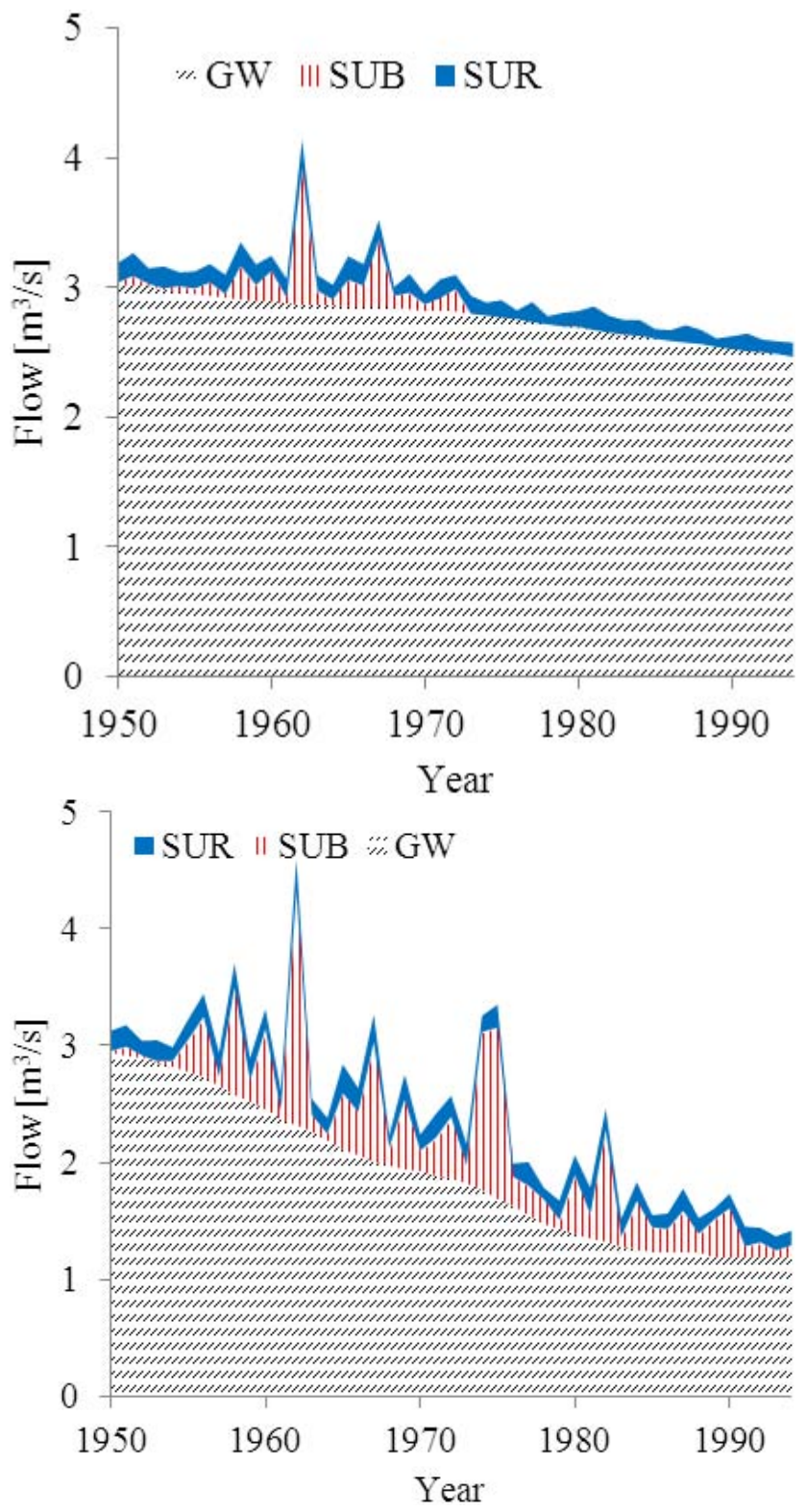

Fig. 5. Surface flow (SUR), subsurface flow (SUB) and baseflow (GW) for the non-irrigation (left) and irrigation (right) cases. Groundwater-fed irrigation decreases the slow flow component (GW) and increases fast flow components (SUR and SUB), leading to a streamflow more subjected to climate variability. The conversion from natural grassland to irrigated cropland leads to a decrease of slow components, due to depletion of aquifer discharge by pumping. The increased soil moisture during growing season increases subsurface lateral flow and surface runoff during storm events.

The streamflow under agricultural development is shown in Fig. 5 with only land use change (non-irrigation scenario) and with both land use change and irrigation (irrigation scenario). For the non-irrigation scenario, the mean streamflow is 3.22 and $2.77 \mathrm{~m}^{3} \mathrm{~s}^{-1}$ during pre-1970s and post-1970s periods, respectively. For the irrigation scenario,

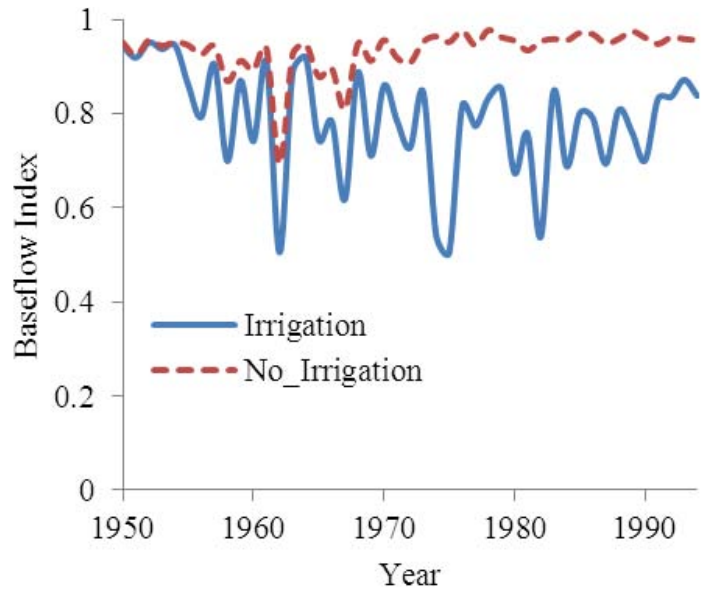

Fig. 6. Baseflow index for non-irrigation and irrigation cases.

the mean streamflow is 3.05 and $1.93 \mathrm{~m}^{3} \mathrm{~s}^{-1}$ during pre1970s and post-1970s periods, respectively. Note that the streamflow from the pre-1970s periods is not significantly different among these scenarios, since large-scale agricultural development and groundwater pumping had just started at that time. Comparing the flow pre-1970s under the three scenarios shows that groundwater pumping amounts to a $0.84 \mathrm{~m}^{3} \mathrm{~s}^{-1}$ decrease in streamflow, more than twice as that caused by land use at $0.31 \mathrm{~m}^{3} \mathrm{~s}^{-1}$.

\subsection{Flow component change}

The SWAT model simulates three flow components (i.e., baseflow, subsurface flow and overland runoff), which enable us to decompose the effect of groundwater-fed irrigation on streamflow. In Fig. 5, the surface flow, subsurface flow from the soil profile, and baseflow from the aquifer discharge are denoted as SUR, SUB and GW, respectively. As mentioned earlier, streamflow is decomposed to a slow component (corresponding to a sustained baseflow from aquifer) and a fast flow component (corresponding to runoff from surface and unsaturated zone), which has a shorter travel time and is more prone to climate variability. Although the streamflow decreases under both scenarios (land use only, land use and irrigation), the changes on the different flow components are significantly different. In the non-irrigation scenario, all flow components decrease, especially for the subsurface flow, which is nearly zero after the 1970s. For the groundwater-fed irrigation scenario, the decrease is mainly from aquifer discharge (i.e., from 2.56 to $1.41 \mathrm{~m}^{3} \mathrm{~s}^{-1}$ ), while surface flow decreases slightly from 0.177 to $0.154 \mathrm{~m}^{3} \mathrm{~s}^{-1}$ and subsurface flow increases from 0.311 to $0.362 \mathrm{~m}^{3} \mathrm{~s}^{-1}$. As a result, return flow from irrigation partially compensates the stream depletion by groundwater pumping. This also implies that ignoring irrigation return flow would overestimate stream depletion by aquifer pumping. 


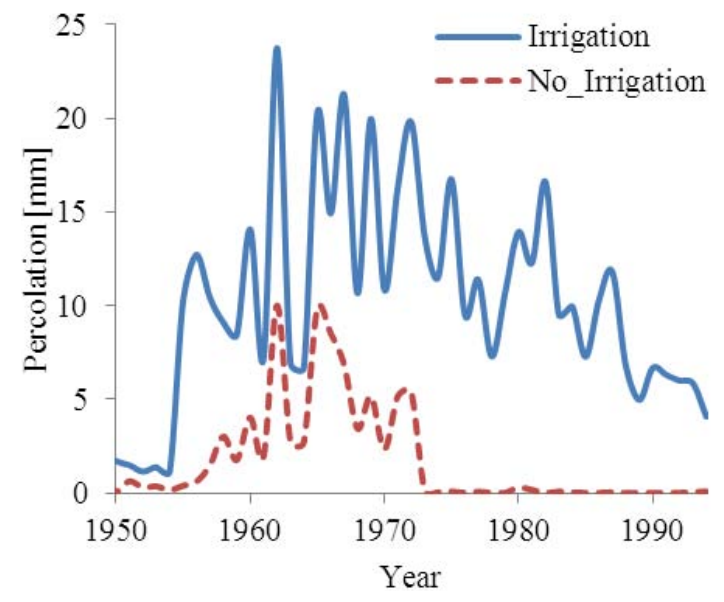

Fig. 7. Soil profile percolation for non-irrigation and irrigation cases.

Aquifer discharge provides streams with a stable flow (i.e., slow flow component) and is relatively insensitive to climate variation; while surface and subsurface flow is prone to climate variability (i.e., temperature, and vapor pressure) through soil moisture dynamics, vegetation water use or human water management (Harman et al., 2011). Thus, surface and subsurface flow convert the climatic variability into streamflow variability and exhibit as fast flow components. The baseflow index (BFI, ratio of baseflow in total streamflow) is shown in Fig. 6 for irrigation and non-irrigation scenarios. The BFI decreases from 95 to $75 \%$ due to groundwater pumping and irrigation return flow. As shown in Fig. 6, the baseflow accounts for $70-80 \%$ of the total flow. The baseflow indices calculated from a recursive digital filter (Santhi et al., 2008) and the US Geological Survey $1 \mathrm{~km}$ baseflow index data set (Wolock, 2003) show similar values to our results (i.e., between 69 and $76 \%$ ).

The effects of stream depletion and irrigation return flow change the ratio of the fast and slow flow components in stream, leading to changes in streamflow variability. The coefficient of variation $(\mathrm{CoV})$ of streamflow under the irrigation case is 0.077 and 0.151 for pre- and post-1970s periods, respectively. In watersheds with intensive agricultural activities streamflow components are affected by crop water consumption and water management. Thus besides climatic variability, human interference (irrigation, return flow) is also an important factor to affect the stream variability by changing the dynamics of surface water and groundwater interaction.

\subsection{Aquifer recharge-discharge pattern change}

Associated with the streamflow changes, the pumping for irrigation and return flow also change the temporal pattern of aquifer storage. The increased soil moisture by irrigation application increases subsurface flow. Meanwhile the increased soil moisture also helps recharge the aquifer through soil pro-

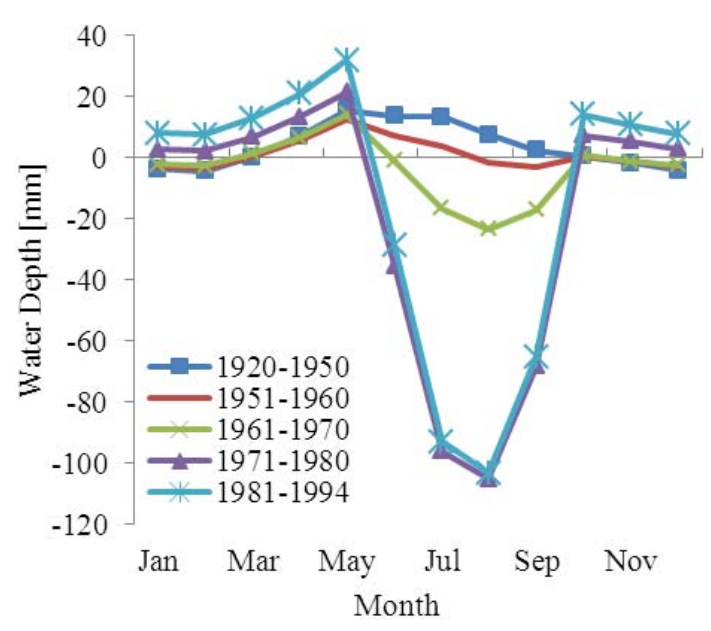

Fig. 8. Monthly aquifer storage change averaged by decades (storage change before the 1950s is not simulated in this model and is adapted from the RRCA).

file percolation. Figure 7 shows the soil percolation, which is considerably higher under the irrigation scenario than the non-irrigation one. Especially after 1973, the soil profile percolation is nearly zero in the non-irrigation case, since soil moisture in a large portion of the watershed is lost to the atmosphere through crop evapotranspiration. While for the irrigated case, irrigation maintains soil moisture and then soil profile percolation over the years.

Aquifer storage change results from the combined effect of aquifer recharge, pumping, aquifer discharge to river and other fluxes (i.e., deep root vegetation evapotranspiration). The monthly aquifer storage change regime is averaged by decades, as shown in Fig. 8. During periods when irrigation intensity is low, the aquifer is recharged during summer from May to July due to precipitation-dominant recharge and discharged in winter to sustain the baseflow in streams since the precipitation is relatively low in winter. Recharge to the aquifer in summer from 1920 to 1950 is also shown by the RRCA groundwater model. With agricultural development, aquifer storage experiences significant decreases in the crop growth season (June-September, which covers the whole summer in the region) due to pumping and high evapotranspiration. However, aquifer storage recovers during winter and spring by the return flow, which is delayed from irrigation application in summer. The maximum monthly storage decline occurs in August, when pumping is most intensive. Figure 9 shows the declining trend of aquifer storage during the period of 1951-1994. Since the SWAT model does not simulate the water table, the aquifer storage is expressed in equivalent water depth (i.e., millimeter) by averaging the groundwater storage of all subbasins annually. Since late $1960 \mathrm{~s}$, the accumulative groundwater storage has declined about $5500 \mathrm{~mm}$ in equivalent water depth. The actual water table change can be estimated by dividing the aquifer storage change by the specific yield. The typical value of 


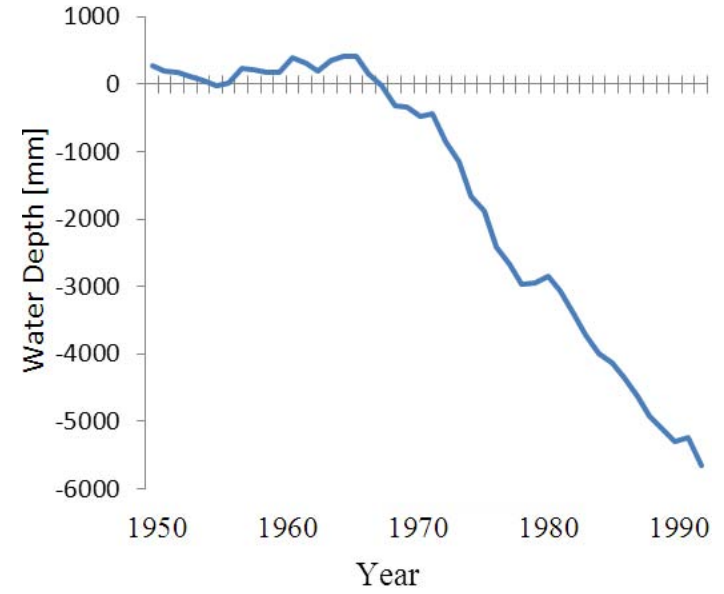

Fig. 9. Accumulative aquifer storage change.

specific yield in the area is 0.175 (the value used in the RRCA model). Thus the average water table decrease in the FCB is about $31.5 \mathrm{~m}$, which is validated by the area-weighted average from observation wells (McGuire, 2009). Aquifer storage depletion started in the 1960s, reached the maximum during the 1970s, and remained stable since then. During the 1980s, the aquifer storage depletion recovers slightly, which corresponds to the irrigation regulation within the region started in the late 1980s. According to the records of the US Geological Survey (USGS), the water table in the aquifer remains in a declining trend but at a slower rate in recent years (McGuire, 2012). The decline of the aquifer storage during the period 2009-2011 is estimated as 2.8 million acre$\mathrm{ft}$., equivalent to $0.1 \mathrm{ft}$. decline in the water table. Thus, the intensive pumping reverses the natural seasonal groundwater recharge pattern, from "summer recharge and winter discharge" under natural conditions to "summer discharge and winter recharge" under the human interferences.

\section{Conclusions}

Streamflow change is a result of climate forcings, catchment properties and human activities in watersheds around the world. At the study site discussed in this paper, streamflow records at the gauging stations reflect the synthetical effect of dynamic interactions between surface water and groundwater systems, which are enhanced by groundwater pumping and return flow with heavy groundwater-fed irrigation. In this study, a modeling analysis based on a modified SWAT model is applied to analyze the conjunctive effects of pumping and irrigation return flow on streamflow. By relating baseflow to shallow aquifer storage through a linear reservoir model, the streamflow response to groundwater pumping is explicitly simulated, and the synthetic effects of two types of human interferences (i.e., pumping and return flow) are assessed. While irrigation return flow partially compensates the decrease in streamflow, the stream depletion trend due to groundwater pumping has been revealed by the model as comparable to the observed. However, the fast flow component (surface and subsurface flow) increases due to return flow and the slow flow component (baseflow) decreases due to groundwater pumping. As a result, the streamflow is altered from a baseflow dominant regime to one that is more influenced by surface and subsurface flow. The change among baseflow, subsurface and surface flow components due to human interferences is modeled for the first time, according to our knowledge, which allows a close examination of the streamflow variability, rooted with climatic variability but aggravated by human interferences (groundwater pumping and return flow). Agricultural water use in this region has shifted the groundwater seasonal regime from the pattern of "summer recharge and winter discharge" in the past to "summer discharge and winter recharge" at present. This could affect the ecosystems that depend on the streamflow regime. Moreover the shift challenges existing groundwater modeling, which usually assumes fixed recharge patterns and rates.

Although the modified model can simulate streamflow response to groundwater pumping, it only represents one way of the stream-aquifer interaction, that is, flow from aquifer to stream. This limits the model to simulate the situation where groundwater pumping inverses stream-aquifer interaction. This model is valid in a headwater zone such as FCB, where baseflow is sustained by the aquifer, but may not be applicable to areas where streamflow recharges the aquifer. Also, the SWAT model is semi-distributed, that is, each hydrological representative unit is only connected with each other by river network and no interaction exists due to the water table gradient. Thus, the assessment of aquifer storage is averaged from all subbasins. Improvement of the subbasin aquifer storage connection would provide the spatial impact of groundwater movement. If spatial information (e.g., impact of the location of pumping wells relative to streams, the location of drawdown cones, etc.) is included, the groundwater movement under human interferences can be better understood.

We admit that the model presented (even with our modification) is not ideal for simulating the sophisticated relationship between irrigation pumping and streamflow, which involves the dynamic interactions of surface water and groundwater. As discussed in the introduction, both surface hydrology and groundwater communities assess the streamaquifer interaction from different aspects. Simulation models from both communities have a different focus with respect to their interests. However, surface water and groundwater are a holistic entity that requires an integrated modeling approach, which is currently not well developed. We believe the modification of a widely used watershed management model (SWAT) can serve the purpose of analysis, especially for the understanding of agricultural development and streamflow change. Our study presents an effort to improve the watershed model to better assess basin-wide surface water and groundwater interaction with intensive agricultural 
activities. Indeed the model results provide some insights on the impact of irrigation on streamflow through a highly nonlinear process. From a modeler's perspective, both the improvement and the limitation of this model provide experiences for further development of an integrated surface watergroundwater model.

Acknowledgements. This study was financially supported by the US National Science Foundation grants CMMI 0825654 and CBET-0727476. The authors thank the three anonymous reviewers for their comments and suggestions, which helped to improve this paper.

Edited by: D. Gerten

\section{References}

Adegoke, J. O., Pielke, R. A., Eastman, J., Mahmood, R., and Hubbard, K. G.: Impact of Irrigation on Midsummer Surface Fluxes and Temperature under Dry Synoptic Conditions: A Regional Atmospheric Model Study of the U.S. High Plains, Mon. Weather Rev., 131, 556-564, doi:10.1175/15200493(2003)131<0556:IOIOMS>2.0.CO;2, 2003.

Alley, W. M., Healy, R. W., LaBaugh, J. W., and Reilly, T. E.: Flow and storage in groundwater systems, Science, 296, 1985-1990, 2002.

Arnold, J. G., Srinivasan, R., Muttiah, R. S., and Williams, J.: Large area hydrologic modeling and assessment part I: Model development1, JAWRA J. Am. Water Resour. Assoc., 34, 73-89, 1998.

Burt, O. R., Baker, M., and Helmers, G. A.: Statistical estimation of streamflow depletion from irrigation wells, Water Resour. Res., 38, 1296, doi:10.1029/2001wr000961, 2002.

Chow, V. T., Maidment, D. R., and Mays, L. W.: Applied hydrology, Mc-Graw Hill, New York, 1988.

DeAngelis, A., Dominguez, F., Fan, Y., Robock, A., Kustu, M. D., and Robinson, D.: Evidence of enhanced precipitation due to irrigation over the Great Plains of the United States, J. Geophys. Res.-Atmos., 115, D15115, doi:10.1029/2010JD013892, 2010.

Ferguson, I. M. and Maxwell, R. M.: Hydrologic and land-energy feedbacks of agricultural water management practices, Environ. Res. Lett., 6, 014006, doi:10.1088/1748-9326/6/1/014006, 2011.

Ferguson, I. M. and Maxwell, R. M.: Human impacts on terrestrial hydrology: climate change versus pumping and irrigation, Environ. Res. Lett., 7, 044022, doi:10.1088/1748-9326/7/4/044022, 2012.

Gassman, P. W., Reyes, M. R., Green, C. H., and Arnold, J. G.: The Soil and Water Assessment Tool: Historical development, applications, and future research directions, Trans. ASABE, 50, 1211-1250, 2007.

Gleeson, T., Alley, W. M., Allen, D. M., Sophocleous, M. A., Zhou, Y., Taniguchi, M., and VanderSteen, J.: Towards Sustainable Groundwater Use: Setting Long-Term Goals, Backcasting, and Managing Adaptively, Ground Water, 50, 19-26, doi:10.1111/j.1745-6584.2011.00825.x, 2012.

Gosain, A. K., Rao, S., Srinivasan, R., and Reddy, N. G.: Returnflow assessment for irrigation command in the Palleru river basin using SWAT model, Hydrol. Process., 19, 673-682, doi:10.1002/hyp.5622, 2005.
Gutentag, E. D.: Geohydrology of the High Plains aquifer in parts of Colorado, Kansas, Nebraska, New Mexico, Oklahoma, South Dakota, Texas, and Wyoming, Geological Survey professional paper, 1400-B, 1984.

Harman, C. J., Troch, P. A., and Sivapalan, M.: Functional model of water balance variability at the catchment scale: 2 . Elasticity of fast and slow runoff components to precipitation change in the continental United States, Water Resour. Res., 47, W02523, doi:10.1029/2010WR009656, 2011.

HPRCC: Historical climate data summaries, Univ. of NebraskaLincoln, Lincoln, NE, available at: http://www.hprcc.unl.edu/ data/historical/ (last access: 27 May 2010), 2010.

Jenkins, C.: Techniques for Computing Rate and Volume of Stream Depletion by Wellsa, Ground Water, 6, 37-46, 1968.

Kendy, E. and Bredehoeft, J. D.: Transient effects of groundwater pumping and surface-water-irrigation returns on streamflow, Water Resour. Res., 42, W08415, doi:10.1029/2005wr004792, 2006.

Kenny, J. F., Barber, N. L., Hutson, S. S., Linsey, K. S., Lovelace, J. K., and Maupin, M. A.: Estimated use of water in the United States in 2005, available at: http://pubs.usgs.gov/circ/1344/pdf/ c1344.pdf, Circular 1344, US Geological Survey, Reston, VA, 2009.

Konikow, L. F.: Contribution of global groundwater depletion since 1900 to sea-level rise, Geophys. Res. Lett., 38, L17401, doi:10.1029/2011GL048604, 2011.

Malcolm, I. A., Soulsby, C., Hannah, D. M., Bacon, P. J., Youngson, A. F., and Tetzlaff, D.: The influence of riparian woodland on stream temperatures: implications for the performance of juvenile salmonids, Hydrol. Process., 22, 968-979, doi:10.1002/hyp.6996, 2008.

McGuire, V. L.: Water-level changes in the High Plains aquifer, predevelopment to 2007, 2005-06, and 2006-07, US Geological Survey Scientific Investigations Report, 2009-5019, p. 9, available at: http://pubs.usgs.gov/sir/2009/5019/, 2009.

McGuire, V. L.: Changes in Water Levels and Storage in the High Plains Aquifer, Predevelopment to 2009, US Geological Survey Fact Sheet, 2011-3069, p. 2, available at: http://pubs.usgs.gov/ preview/fs/2011/3069/, 2011.

McGuire, V.: Water-Level and Storage Changes in the High Plains Aquifer, Predevelopment to 2011 and 2009-11, US Geological Survey Scientific Investigations Report, 2012-5291, p. 15, available at: http://pubs.usgs.gov/sir/2012/5291/, 2012.

Miller, J. A., Appel, C. L., Ulibarri, L. J., Dunagan, D. L., and Latzke, G. D.: Ground Water Atlas of the United States: Kansas, Missouri and Nebraska, Segment 3 Hydrol. Atlas 730-D, 24 pp., US Geological Survey, Reston, Va., 1997.

Rodriguez-Iturbe, I., Porporato, A., Ridolfi, L., Isham, V., and Coxi, D. R.: Probabilistic modelling of water balance at a point: the role of climate, soil and vegetation, Proc. Roy. Soc. London A, 455, 3789-3805, doi:10.1098/rspa.1999.0477, 1999.

Santhi, C., Allen, P. M., Muttiah, R. S., Arnold, J. G., and Tuppad, P.: Regional estimation of base flow for the conterminous United States by hydrologic landscape regions, J. Hydrol., 351, 139153, doi:10.1016/j.jhydrol.2007.12.018, 2008.

Schmid, W., Hanson, R., Maddock III, T., and Leake, S.: User guide for the farm process (FMP1) for the US Geological Survey's modular three-dimensional finite-difference ground-water flow 
model, MODFLOW-2000, US Geological Survey Techniques and Methods 6-A17, Reston, Virginia, 2006.

Siebert, S., Burke, J., Faures, J. M., Frenken, K., Hoogeveen, J., Döll, P., and Portmann, F. T.: Groundwater use for irrigation - a global inventory, Hydrol. Earth Syst. Sci., 14, 1863-1880, doi:10.5194/hess-14-1863-2010, 2010.

Sophocleous, M.: Review: groundwater management practices, challenges, and innovations in the High Plains aquifer, USA lessons and recommended actions, Hydrogeol. J., 18, 559-575, doi:10.1007/s10040-009-0540-1, 2010.

Sophocleous, M. and Perkins, S. P.: Methodology and application of combined watershed and ground-water models in Kansas, J. Hydrol., 236, 185-201, doi:10.1016/S0022-1694(00)00293-6, 2000.

Swinehart, J. B. and Richmond, G. M.: Quaternary geologic map of the Platte River 4 X 6 Quadrangle, United States, US Geological Survey Misc. Invest. Series Map I-1420 (NK-14), scale $1: 1000000,1994$.

Szilagyi, J.: Identifying Cause of Declining Flows in the Republican River, J. Water Resour. Plann. Manage., 127, 244-253, doi:10.1061/(ASCE)0733-9496(2001)127:4(244), 2001.
Tang, Q., Oki, T., Kanae, S., and Hu, H.: The Influence of Precipitation Variability and Partial Irrigation within Grid Cells on a Hydrological Simulation, J. Hydrometeorol., 8, 499-512, doi:10.1175/JHM589.1, 2007.

Theis, C. V.: The source of water derived from wells, Civil Eng., 10, 277-280, 1940.

USDA, C. P.: National Agricultural Statistics Service, Government Printing Office, Washington DC (annual issues, 1965-2002), 1999.

Wada, Y., van Beek, L. P. H., and Bierkens, M. F. P.: Nonsustainable groundwater sustaining irrigation: A global assessment, Water Resour. Res., 48, W00L06, doi:10.1029/2011wr010562, 2012.

Wolock, D. M.: Base-flow index grid for the conterminous United States, US Geological Survey Open-File Report 03-263, digital data set, available at: http://water.usgs.gov/lookup/getspatial? bfi48grd, 2003.

Zeng, R.: Infrastructure planning for drought mitigation under climate change, Master thesis, University of Illinois at UrbanaChampaign, Urbana, IL, USA, 2012. 